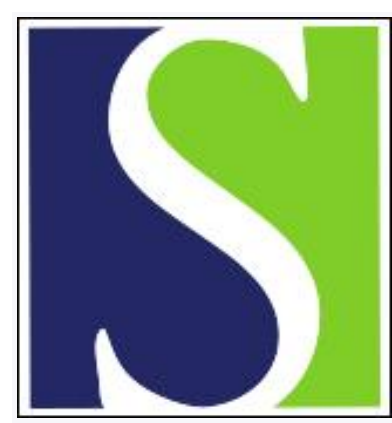

Scand J Work Environ Health 1992;18(4):217-224

https://doi.org/10.5271/sjweh.1586

Issue date: 01 Aug 1992

Cancer incidence and mortality among Swedish Baltic Sea fishermen.

by Hagmar L, Linden K, Nilsson A, Norrving B, Akesson B, Schutz A, Moller T

Affiliation: Department of Occupational and Environmental Medicine, University Hospital, Lund, Sweden.

The following article refers to this text: 2020;46(5):461-468

This article in PubMed: www.ncbi.nlm.nih.gov/pubmed/1411363 


\title{
Cancer incidence and mortality among Swedish Baltic Sea fishermen
}

\author{
by Lars Hagmar, MD, ${ }^{1}$ Katarina Lindén, BSc, ${ }^{1}$ Anita Nilsson, $\mathrm{RN},{ }^{1}$ Bo Norrving, MD, ${ }^{2}$ \\ Björn Åkesson, MD, ${ }^{3}$ Andrejs Schütz, ${ }^{1}$ Torgil Möller, MD ${ }^{4}$
}

\begin{abstract}
HAGMAR L, LINDÉN K, NILSSON A, NORRVING B, ÅKESSON B, SCHÜTZ A, MÖLLER T. Cancer incidence and mortality among Swedish Baltic Sea fishermen. Scand J Work Environ Health 1992; 18:217-24. A $25 \%$ lower cancer mortality was found for 1360 Swedish fishermen who fished on the Baltic Sea than for the general population. The fishermen consumed twice as much fish as the population in the same county. In spite of the low overall cancer mortality, increased mortality from myeloma, as well as increased incidences of gastric carcinoma and squamous cell cancer of the skin and lips, was observed in the cohort. The decrease in risk for ischemic heart disease was not significant. Whether the dietary intake of fatty acids and selenium from fish contributed to the decreased risk was difficult to evaluate. Moreover, whether the consumption of fish from the Baltic Sea, contaminated with, for example, polychlorinated dioxins and dibenzofurans and other persistent organochlorine substances, contributed to the observed increased specific cancer risks is not known. However, the net health effect of high fish consumption from the Baltic Sea seems to be positive.
\end{abstract}

Key terms: cerebrovascular diseases, ischemic heart disease, mercury, multiple myeloma, polychlorinated biphenyls, polychlorinated dibenzo p-dioxins and furans, selenium, squamous cell cancer, stomach neoplasms, n-3 polyunsaturated fatty acids.

Since World War II, the Baltic Sea has been contaminated with several persistent organochlorine substances such as dichlorodiphenyltrichloroethane (DDT) and polychlorinated biphenyls (PCB). The chlorine bleaching process in the pulp industry forms polychlorinated dibenzo-p-dioxins and furans $(1,2)$. This has been a very important source emitting organochlorine substances into the Baltic Sea. Dibenzo-p-dioxins and furans are very fat soluble and accumulate in marine organisms. Some of the dibenzo-p-dioxins and furans are extraordinarily toxic $(1,2)$ or are animal carcinogens (3). Moreover, DDT and PCB are also well known animal carcinogens (3). Subjects with a high consumption of mainly fat fish from the Baltic Sea have considerably increased blood levels of dibenzo-p-dioxins and furans, as compared with subjects with a low dietary fish intake (4).

However, high fish consumption cannot be regarded only as a potential risk factor. A low incidence of myocardial infarction has been observed among Inuits in Greenland (5), and this low incidence was related to their traditional diet of seafood. Fat fish, as well as

1 Department of Occupational and Environmental Medicine, University Hospital, Lund, Sweden.

2 Department of Neurology, University Hospital, Lund, Sweden.

3 Department of Medical Chemistry, University of Lund, Sweden.

4 Regional Tumor Registry, University Hospital, Lund, Sweden.

Reprint requests to: Dr L Hagmar, Department of Occupational and Environmental Medicine, University Hospital, S-221 85 Lund, Sweden. seals and whales, contain much $n-3$ polyunsaturated fatty acids (n-3 PUFA) (eg, eicosapentaenoic acid) (6). It has been suggested that high dietary levels of $n-3$ PUFA may be protective against atherosclerotic cardiovascular disease by reducing thrombocyte aggregation and increasing bleeding time $(7,8)$ or by reducing the plasma levels of cholesterol and triglycerides $(9,10)$. In contrast to the low incidence of death from myocardial infarction among Inuits, an increased incidence of death from stroke was observed $(5,11)$. It has been suggested that a reduced platelet aggregation ability may increase the risk of hemorrhagic stroke (5). It is important to gain increased knowledge about positive and negative effects of fish consumption on public health, as it may have implications for dietary recommendations.

The objective of the present study was to investigate mortality pattern and cancer morbidity in a cohort of Baltic Sea fishermen and to study to what extent their fish consumption was higher than that of the general Swedish population.

\section{Subjects and methods}

Cohort

From a fishermen's organization covering the southeast coast of Sweden, records with name, date of birth, address, and date of start and end of membership were collected for 1371 male fishermen who had been members of the organization for $\mathbf{1 2}$ months or more during the period 1 January 1944 to 31 December 1987. 
It should be noted that the records contained no data on members who had stopped their membership or died before 1968 .

Vital status was determined up to 31 December 1987 (table 1) for all but 11 subjects $(0.8 \%)$, whose ten-digit personal identification codes could not be obtained. Thus the study cohort consisted of 1360 subjects. Table 2 shows the distribution of person-years by age group and calendar year.

\section{Information on causes of death and tumors}

Information on cause of death (1968-1987) was obtained from Statistics Sweden. The death certificates were coded according to the International Classification of Diseases (ICD). All of the codes were transformed to the 8th revision of the ICD. A total of $36 \%$ of the death certificates was based on clinical or forensic autopsy.

Information on up to two tumors (coded according to the ICD, 7th revision), diagnosed from 1968 to 1987 , was obtained from the National Swedish Tumor Register and the Southern Swedish Regional Tumor Register.

\section{Risk estimates}

The expected mortality for the period 1968-1987 was calculated with the use of mortality rates specific for calendar year, cause, and five-year age groups for men in the county (Blekinge; about 75000 male inhabitants). These rates were calculated from death and population counts obtained from Statistics Sweden. Similarly, yearly morbidity rates for cancer in the period 1968-1987 were obtained for the county from the Southern Swedish Regional Tumor Register. Date

Table 1. Vital status of a cohort of Swedish fishermen as of 31 December 1987.

\begin{tabular}{lcc}
\hline Vital status & $\mathrm{N}$ & $\%$ \\
\hline Living & 1085 & 79.1 \\
Dead & $274^{\mathrm{a}}$ & 20.0 \\
Emigrated & 1 & 0.1 \\
Not identified $^{\mathrm{b}}$ & 11 & 0.8 \\
\hline Total & 1371 & 100 \\
\hline
\end{tabular}

a For one person, the cause of death could not be established.

b A ten-digit personal identification code could not be obtained.

Table 2. Person-years under observation in a cohort of Swedish fishermen.

\begin{tabular}{lrrrr}
\hline \multirow{2}{*}{ Calendar-year } & \multicolumn{4}{c}{ Age (years) } \\
\cline { 2 - 5 } & $<30$ & $30-59$ & $>59$ & Total \\
\hline $1968-1975$ & 1261 & 4136 & 1987 & 7384 \\
$1976-1980$ & 820 & 2679 & 1582 & 5081 \\
$1981-1987$ & 1164 & 3940 & 2627 & 7731 \\
\hline Total & 3246 & 10754 & 6196 & 20196 \\
\hline
\end{tabular}

of death or emigration was used as the individual end point.

\section{Dietary interviews}

From the cohort, 50 randomly chosen fishermen were selected. For each of them, a male referent, matched with respect to age, was selected from the population register of the same county. We were able to interview 47 fishermen and 46 referents over the telephone about their food frequencies for 27 different food items, as well as for their coffee, tobacco, and alcohol consumption. Moreover, color pictures of three different sizes of fish portions of four fish species common in the Baltic Sea were distributed to all of the interviewed subjects before the interview. They were asked which size most resembled their usual fish portion of cod (115, 190 or $300 \mathrm{~g})$, herring $(135,225$ or $360 \mathrm{~g})$, salmon (135, 225 or $360 \mathrm{~g})$, or flatfish $(280,545$ or $865 \mathrm{~g})$. The average weekly consumption was then calculated from the frequencies and portion sizes indicated.

\section{Blood and urine samples}

Blood and urine samples were collected from a random subsample of 30 fishermen, out of the aforementioned 50. Blood was collected in metal-free evacuated tubes from the cubital vein with heparin as the anticoagulant for the mercury assays and with ethylenediaminetetraacetic acid (EDTA) as the anticoagulant for the selenium assays. The samples were centrifuged at $2000 \mathrm{~g}$ for $10 \mathrm{~min}$, and the supernatant plasma was drawn off for further analyses. The buffy coat was discarded. Urine was collected in acid-washed polyethylene bottles. Unless the samples were analyzed immediately, they were kept at $-20^{\circ} \mathrm{C}$ until analysis.

\section{Analytical procedures}

Fatty acid composition in phosphatidylcholine was determined as described elsewhere (12). The mercury content in urine, plasma, and red blood cells was determined in wet-digested samples by a "cold vapor" atomic absorption technique using automatic equipment, as described elsewhere (13). All of the samples were analyzed in duplicate. The coefficient of variation was $7.5 \%$ (mean $1.7 \mathrm{ng} \cdot \mathrm{g}^{-1}$ ) for plasma, $9.0 \%$ (mean $7.7 \mathrm{ng} \cdot \mathrm{g}^{-1}$ ) for erythrocytes, and $9.0 \%$ (mean $2.0 \mu \mathrm{g} \cdot \mathrm{l}^{-1}$ ) for urine. Analysis of a reference wholeblood sample (Seronorm ${ }^{\circledR}$, Nycomed, Oslo, Norway) gave 9.0 (SD 0.37) $\mathrm{ng} \cdot \mathrm{g}^{-1}(\mathrm{~N}=12)$ as compared with the recommended $9.7(\mathrm{SD} 0.49) \mathrm{ng} \cdot \mathrm{g}^{-1}$. Analysis of a reference urine sample $\left(\right.$ Seronorm ${ }^{\circledR}$ ) gave 52 (SD 1.3) $\mu \mathrm{g} \cdot 1^{-1}(\mathrm{~N}=4)$ as compared with the recommended $52 \mu \mathrm{g} \cdot \mathrm{1}^{-1}$.

Selenium in plasma was determined by a fluorometric method (14). All of the samples were analyzed in duplicate, and the coefficient of variation was $2.7 \%$ (mean $90 \mu \mathrm{g} \cdot 1^{-1}$ ). Analysis of a reference sample 
Table 3. Frequency of fish consumption and estimated average weekly consumption of four species of fish for the 47 fishermen randomly selected from the cohort and 46 referents from the regional reference population matched for age and gender.

\begin{tabular}{|c|c|c|c|c|c|c|c|c|c|c|c|c|c|c|}
\hline \multirow{3}{*}{ Group } & \multicolumn{6}{|c|}{ Fish consumption frequency (meal/week) } & \multicolumn{8}{|c|}{ Weekly consumption (g/week) } \\
\hline & \multicolumn{2}{|c|}{ Lean fish } & \multicolumn{2}{|c|}{ Fat Fish } & \multicolumn{2}{|c|}{ Total } & \multicolumn{2}{|c|}{ Cod filet } & \multicolumn{2}{|c|}{ Flatfish } & \multicolumn{2}{|c|}{ Salmon } & \multicolumn{2}{|c|}{ Herring } \\
\hline & Mean & SD & Mean & SD & Mean & $\mathrm{SD}$ & Mean & SD & Mean & SD & Mean & SD & Mean & SD \\
\hline $\begin{array}{l}\text { Fishermen } \\
\text { Referents }\end{array}$ & $\begin{array}{l}1.5 \\
0.9\end{array}$ & $\begin{array}{l}0.8 \\
0.5\end{array}$ & $\begin{array}{l}1.2 \\
0.7\end{array}$ & $\begin{array}{l}0.7 \\
0.6\end{array}$ & $\begin{array}{l}2.6 \\
1.6\end{array}$ & $\begin{array}{l}1.2 \\
0.9\end{array}$ & $\begin{array}{l}226 \\
118\end{array}$ & $\begin{array}{r}158 \\
93\end{array}$ & $\begin{array}{l}339 \\
140\end{array}$ & $\begin{array}{l}327 \\
156\end{array}$ & $\begin{array}{l}73 \\
45\end{array}$ & $\begin{array}{l}87 \\
79\end{array}$ & $\begin{array}{l}172 \\
102\end{array}$ & $\begin{array}{l}118 \\
105\end{array}$ \\
\hline P-value a & \multicolumn{2}{|c|}{0.0001} & \multicolumn{2}{|c|}{0.001} & \multicolumn{2}{|c|}{$<0.0001$} & \multicolumn{2}{|c|}{0.0001} & \multicolumn{2}{|c|}{0.0002} & \multicolumn{2}{|c|}{0.03} & \multicolumn{2}{|c|}{0.003} \\
\hline
\end{tabular}

Mann-Whitney U-test.

$\left(\right.$ Seronorm $\left.{ }^{\circledR}\right)$ gave $87(\mathrm{SD} 3.3) \mu \mathrm{g} \cdot 1^{-1}(\mathrm{~N}=8)$ as compared with the recommended $90 \mu \mathrm{g} \cdot \mathrm{1}^{-1}$.

Creatinine in urine was analyzed according to a modified kinetic Jaffé method (15), with a coefficient of variation of $6 \%$.

\section{Clinical diagnosis of stroke among the fishermen and matched referents}

For each of the 33 subjects in the cohort who, during the period 1968-1986, had died from cerebrovascular diseases (ICD 8th revision, 430-438) two deceased referents matched for age at death, calendar year of death, gender, hospital code, and ICD code interval were selected from the cause-of-death register. Hospital records or autopsy protocols could be obtained for all of the fishermen and for 62 of the 66 referents. The records were blindly scrutinized by a neurologist who used the available information to determine the probability of infarction or hemorrhage by means of a validated clinical score (Allen Score) (16). Scoring could, however, be performed for only 28 fishermen and 46 referents. Reasons for exclusions were clinical criteria for a diagnosis of stroke not fulfilled (12 subjects), other neurological disease than stroke established (5 subjects), and cerebral hemorrhage occurring during anticoagulant therapy (4 subjects).

\section{Statistical methods}

Cause-specific standardized mortality or morbidity ratios and $95 \%$ confidence intervals were calculated according to the Poisson distribution or according to the chi-square distribution if the expected values were greater than 10. The Mann-Whitney U-test was used for evaluating differences in fish, alcohol, and tobacco consumption between the fishermen and the referents. A multiple regression analysis allowing for age at death, calendar year of death, and hospital code was used for testing differences in stroke scores between the deceased fishermen and referents.

The term "significant" refers to $P \leq 0.05$ or to a $95 \%$ confidence interval $(95 \% \mathrm{CI})$ for the standardized morbidity or mortality ratio (SMR) that does not include 1.00 . All of the tests were two-tailed.
Table 4. Estimated food frequencies $10-20$ years ago for the 47 fishermen randomly selected from the cohort and the 46 referents from the reference population, matched by age and gender.

\begin{tabular}{|c|c|c|c|}
\hline & $\begin{array}{c}\text { Fisher- } \\
\text { men }\end{array}$ & Referents & $\mathbf{p a}^{\mathbf{a}}$ \\
\hline \multicolumn{4}{|l|}{ Fish consumption } \\
\hline $\begin{array}{l}\text { Ate much more earlier } \\
\text { Ate more earlier } \\
\text { Unchanged } \\
\text { Ate less earlier } \\
\text { Ate much less earlier }\end{array}$ & $\begin{array}{r}1 \\
7 \\
33 \\
5 \\
1\end{array}$ & $\begin{array}{r}4 \\
9 \\
18 \\
8 \\
7\end{array}$ & $>0.5$ \\
\hline \multicolumn{4}{|l|}{ Fresh vegetables } \\
\hline $\begin{array}{l}\text { Ate much more earlier } \\
\text { Ate more earlier } \\
\text { Unchanged } \\
\text { Ate less earlier } \\
\text { Ate much less earlier }\end{array}$ & $\begin{array}{r}- \\
2 \\
19 \\
22 \\
4\end{array}$ & $\begin{array}{r}1 \\
2 \\
25 \\
14 \\
4\end{array}$ & 0.17 \\
\hline \multicolumn{4}{|l|}{ Fresh fruits } \\
\hline $\begin{array}{l}\text { Ate much more earlier } \\
\text { Ate more earlier } \\
\text { Unchanged } \\
\text { Ate less earlier } \\
\text { Ate much less earlier }\end{array}$ & $\begin{array}{r}- \\
22 \\
16 \\
6\end{array}$ & $\begin{array}{r}1 \\
5 \\
25 \\
13 \\
2\end{array}$ & 0.08 \\
\hline
\end{tabular}

a Mann-Whitney U-test.

\section{Results}

\section{Fish consumption}

The frequency of fish consumption among the fishermen was almost doubled as compared with that of the referents, irrespective of whether the fish was lean or fat (table 3). Moreover, the average size of the fish meals was significantly bigger among the fishermen for both cod $(P=0.01)$, flatfish $(P<0.0001)$, herring $(P=0.001)$, and salmon $(P=0.04)$. Consequently, the fish intake among the fishermen was increased by 62 to $142 \%$, depending on the fish species (table 3). The fish consumption pattern had not changed significantly in any of the groups as compared with $10-20$ years ago (table 4).

\section{Other dietary habits and coffee, alcohol, and tobacco consumption}

There was no significant difference in food frequency for any other food items, as for example meat, bacon and sausages, fresh vegetables and fruits, between the groups (table 5). The coffee consumption was similarly 
Scand $J$ Work Environ Health 1992, vol 18, no 4

Table 5. Consumption of foods other than fish and the consumption of coffee, alcohol, and tobacco by the 47 fishermen randomly selected from the cohort and the 46 referents from the regional reference population matched for age and gender.

\begin{tabular}{|c|c|c|c|c|c|c|c|c|c|c|c|c|c|c|c|c|}
\hline \multirow[t]{2}{*}{ Group } & \multicolumn{2}{|c|}{$\begin{array}{c}\text { Meat } \\
\text { (meal/week) }\end{array}$} & \multicolumn{2}{|c|}{$\begin{array}{c}\text { Bacon, } \\
\text { sausages } \\
\text { (meal/week) }\end{array}$} & \multicolumn{2}{|c|}{$\begin{array}{c}\text { Fresh } \\
\text { vegetables } \\
\text { (weekly) }\end{array}$} & \multicolumn{2}{|c|}{$\begin{array}{l}\text { Potatoes } \\
\text { (weekly) }\end{array}$} & \multicolumn{2}{|c|}{$\begin{array}{l}\text { Fresh fruit } \\
\text { (weekly) }\end{array}$} & \multicolumn{2}{|c|}{$\begin{array}{c}\text { Coffee } \\
\text { (cups/d) }\end{array}$} & \multicolumn{2}{|c|}{$\begin{array}{c}\text { Aicohol } \\
\text { (g/month) }\end{array}$} & \multicolumn{2}{|c|}{$\begin{array}{c}\text { Tobacco } \\
\text { (pack-years) }^{a}\end{array}$} \\
\hline & Mean & SD & Mean & SD & Mean & $S D$ & Mean & SD & Mean & SD & Mean & SD & Mean & SD & Mean & SD \\
\hline $\begin{array}{l}\text { Fishermen } \\
\text { Referents }\end{array}$ & $\begin{array}{l}2.3 \\
2.5\end{array}$ & $\begin{array}{l}1.1 \\
1.2\end{array}$ & $\begin{array}{l}1.7 \\
1.6\end{array}$ & $\begin{array}{l}1.6 \\
1.2\end{array}$ & $\begin{array}{l}4.7 \\
6.0\end{array}$ & $\begin{array}{l}4.4 \\
4.6\end{array}$ & $\begin{array}{l}6.4 \\
5.9\end{array}$ & $\begin{array}{l}1.6 \\
1.5\end{array}$ & $\begin{array}{l}6.0 \\
5.7\end{array}$ & $\begin{array}{l}5.2 \\
4.6\end{array}$ & $\begin{array}{l}5.4 \\
4.6\end{array}$ & $\begin{array}{l}2.9 \\
2.9\end{array}$ & $\begin{array}{l}23.2 \\
35.0\end{array}$ & $\begin{array}{l}23.8 \\
37.6\end{array}$ & $\begin{array}{l}17.3 \\
11.2\end{array}$ & $\begin{array}{l}18.6 \\
20.0\end{array}$ \\
\hline P-value ${ }^{b}$ & 0.34 & & $>0.5$ & & 0.14 & & 0.06 & & $>0.5$ & & 0.17 & & 0.07 & & 0.03 & \\
\hline
\end{tabular}

a One pack-year $=20$ cigarettes a day for one year or, for example, 10 cigarettes a day for two years.

b Mann-Whitney U-test.

Table 6. Plasma levels of $n-3$ polyunsaturated fatty acids ( $n-3$ PUFA), eicosapentaenoic acid, selenium and mercury $(\mathrm{Hg})$, levels of $\mathrm{Hg}$ in red blood cells $(\mathrm{Ery}-\mathrm{Hg})$, and urinary levels of $\mathrm{Hg}$ in 30 randomly selected fishermen.

n-3 PUFA in plasma (weight \%)

Eicosapentaenoic acid in plasma (weight \%)

Selenium in plasma $\left(\mu \mathrm{g} \cdot \mathrm{I}^{-1}\right)$

Mercury in plasma (ng $\cdot \mathrm{g}^{-1}$ )

Mercury in erythrocytes ( $\mathrm{ng} \cdot \mathrm{g}^{-1}$ )

Urinary mercury $\left(\mu \mathrm{g} \cdot \mathrm{mmol}^{-1}\right.$

creatinine)

\begin{tabular}{cc} 
Mean & Range \\
\hline 10.4 & $6.5-17.9$ \\
2.6 & $0.8-6.9$ \\
90 & $69-118$ \\
1.2 & $0.4-3.2$ \\
7.7 & $1.3-8.1$ \\
0.17 & $0.04-0.33$
\end{tabular}

high in both groups (table 5). The alcohol intake did not significantly differ between the groups (table 5). The lifetime cigarette consumption was increased by about $50 \%$ among the fishermen (table 5).

\section{Fish fatty acids, selenium and mercury}

The plasma levels of n-3 PUFA, eicosapentaenoic acid, selenium, and mercury, the levels of mercury in erythrocytes, and urinary levels of mercury in 30 of the 50 randomly selected fishermen are shown in table 6 . The fish consumption within this subset of fishermen

Table 7. Mortality in the cohort of fisherman by detailed cause in 1968-1987.

\begin{tabular}{|c|c|c|c|c|}
\hline Cause of deatha & $\begin{array}{l}\text { Observed } \\
\text { number of } \\
\text { deaths }\end{array}$ & $\begin{array}{l}\text { Expected } \\
\text { number of } \\
\text { deaths }\end{array}$ & $\begin{array}{l}\text { Standardized } \\
\text { mortality } \\
\text { ratio }\end{array}$ & $\begin{array}{l}95 \% \\
\text { confidence } \\
\text { interval }\end{array}$ \\
\hline All malignant neoplasms $(140-209)$ & 53 & 68.5 & 0.77 & $0.58-1.02$ \\
\hline $\begin{array}{l}\text { Esophagus }(150) \\
\text { Stomach }(151) \\
\text { Rectum }(154) \\
\text { Gallbladder (156) } \\
\text { Pancreas (157) } \\
\text { Lung }(162.1) \\
\text { Skin cancer }(173) \\
\text { Prostate }(185) \\
\text { Bladder (188) } \\
\text { Kidney (189.0) } \\
\text { Unspecified (liver) (197.1) } \\
\text { Brain (191) } \\
\text { Lymphoma, myeloma (200-203) }\end{array}$ & $\begin{array}{r}2 \\
12 \\
2 \\
1 \\
3 \\
9 \\
5 \\
4 \\
1 \\
1 \\
1 \\
8\end{array}$ & $\begin{array}{r}1.2 \\
8.5 \\
3.7 \\
1.1 \\
4.6 \\
12.0 \\
0.2 \\
8.2 \\
2.6 \\
2.8 \\
0.6 \\
1.7 \\
3.6\end{array}$ & $\begin{array}{r}1.64 \\
1.42 \\
0.54 \\
0.96 \\
0.65 \\
0.75 \\
0 \\
0.61 \\
1.55 \\
0.36 \\
1.70 \\
0.59 \\
2.23\end{array}$ & $\begin{array}{l}0.20-5.94 \\
0.73-2.47 \\
0.07-1.95 \\
0.02-5.33 \\
0.13-1.90 \\
0.34-1.42 \\
0.00-18.4 \\
0.20-1.43 \\
0.42-3.97 \\
0.01-2.02 \\
0.04-9.50 \\
0.01-3.29 \\
0.96-4.40\end{array}$ \\
\hline $\begin{array}{l}\text { Hodgkin's lymphoma (201) } \\
\text { Non-Hodgkin's lymphoma }(200,202) \\
\text { Multiple myeloma (203) }\end{array}$ & $\begin{array}{l}- \\
3 \\
5 c\end{array}$ & $\begin{array}{l}0.4 \\
1.7 \\
1.5\end{array}$ & $\begin{array}{r}0 \\
1.79 \\
3.41\end{array}$ & $\begin{array}{l}0.00-9.22 \\
0.37-5.22 \\
1.11-7.96\end{array}$ \\
\hline Leukemia $(204-207)$ & 4 & 2.2 & 1.78 & $0.48-4.55$ \\
\hline $\begin{array}{l}\text { Lymphatic (204) } \\
\text { Myeloid (205) }\end{array}$ & $\begin{array}{l}2 \\
2^{c}\end{array}$ & $\begin{array}{l}1.1 \\
0.9\end{array}$ & $\begin{array}{l}1.85 \\
2.12\end{array}$ & $\begin{array}{l}0.22-6.70 \\
0.26-7.26\end{array}$ \\
\hline Cardiovascular diseases $(390-458)$ & 160 & 174.2 & 0.92 & $0.78-1.07$ \\
\hline Ischemic heart diseases $(410-414)$ & 111 & 123.1 & 0.90 & $0.74-1.07$ \\
\hline Cerebrovascular diseases $(430-438)$ & 34 & 28.6 & 1.19 & $0.83-1.68$ \\
\hline Accidents, poisoning and violence $(800-999)$ & 28 & 20.8 & 1.35 & $0.91-1.97$ \\
\hline $\begin{array}{l}\text { Water transport accidents, drowning } \\
(830-838,910)\end{array}$ & 10 & 0.9 & 11.1 & $5.33-20.4$ \\
\hline All causes $(000-999)$ & 273 & 309.6 & 0.88 & $0.78-0.99$ \\
\hline
\end{tabular}

a Code of the International Classification of Diseases, eighth revision, in parentheses.

b Excluding malignant melanoma and basalioma.

c One of these cases had not been reported to the tumor registries. 
Table 8. Cancer incidence in the cohort of fisherman in 1968-1987.

\begin{tabular}{|c|c|c|c|c|}
\hline Cancer site ${ }^{a}$ & $\begin{array}{l}\text { Observed } \\
\text { number of } \\
\text { cases }\end{array}$ & $\begin{array}{l}\text { Expected } \\
\text { number of } \\
\text { cases }\end{array}$ & $\begin{array}{l}\text { Standardized } \\
\text { morbidity } \\
\text { ratio }\end{array}$ & $\begin{array}{l}95 \% \\
\text { confidence } \\
\text { interval }\end{array}$ \\
\hline Lips (140) & 6 & 1.9 & 3.16 & $1.16-6.88$ \\
\hline Gastrointestinal tract $(150-158)$ & 33 & 34.0 & 0.97 & $0.67-1.37$ \\
\hline $\begin{array}{l}\text { Esophagus (150) } \\
\text { Stomach (151) } \\
\text { Intestine, except rectum (152-153) } \\
\text { Rectum (154) } \\
\text { Liver, bile ducts (155) } \\
\text { Pancreas (157) }\end{array}$ & $\begin{array}{r}-\overline{18} \\
4 \\
4 \\
4 \\
3\end{array}$ & $\begin{array}{r}1.2 \\
10.0 \\
9.3 \\
6.8 \\
2.8 \\
3.9\end{array}$ & $\begin{array}{r}0 \\
1.79 \\
0.43 \\
0.59 \\
1.45 \\
0.77\end{array}$ & $\begin{array}{l}0.00-2.99 \\
1.09-2.88 \\
0.12-1.10 \\
0.16-1.50 \\
0.40-3.72 \\
0.16-2.26\end{array}$ \\
\hline Trachea, bronchus and lung (162-164) & 15 & 13.7 & 1.10 & $0.61-1.81$ \\
\hline Squamus cell cancer of the skin (191) & 20 & 7.2 & 2.79 & $1.73-4.36$ \\
\hline Melanoma of the skin (190) & - & 2.8 & 0 & $0.00-1.32$ \\
\hline Lymphoma, myeloma (200-203) & 8 & 5.4 & 1.47 & $0.64-2.90$ \\
\hline $\begin{array}{l}\text { Hodgkin's lymphoma (201) } \\
\text { Non-Hodgkin's lymphoma }(200,202) \\
\text { Multiple myeloma }(203)\end{array}$ & $\begin{array}{r}- \\
4\end{array}$ & $\begin{array}{l}0.7 \\
3.1 \\
1.6\end{array}$ & $\begin{array}{r}0 \\
1.29 \\
2.48\end{array}$ & $\begin{array}{l}0.00-5.27 \\
0.23-3.25 \\
0.68-6.36\end{array}$ \\
\hline Leukemia (204-209) & 6 & 3.7 & 1.63 & $0.60-3.54$ \\
\hline $\begin{array}{l}\text { Lymphatic leukemia (204) } \\
\text { Myeloid leukemia (205) } \\
\text { Monocyte leukemia (206) }\end{array}$ & $\begin{array}{l}3 \\
2 \\
1\end{array}$ & $\begin{array}{l}2.2 \\
1.4 \\
0.08\end{array}$ & $\begin{array}{r}1.36 \\
1.43 \\
12.52\end{array}$ & $\begin{array}{l}0.28-3.97 \\
0.17-5.16 \\
0.32-69.8\end{array}$ \\
\hline All malignant neoplasms (140-209) & 132 & 119.1 & 1.11 & $0.93-1.32$ \\
\hline
\end{tabular}

a Code of the International Classification of Diseases, seventh revision, in parentheses.

did not differ from that of the men who were interviewed but did not have blood samples taken.

\section{Mortality}

A significant decreased overall mortality was observed among the fishermen (SMR 0.88, 95\% CI 0.78-0.99) (table 7). This decrease was partly due to a lowered cancer mortality (SMR 0.77, 95\% CI 0.58-1.02) and also to a decreased risk of death from cardiovascular disease (SMR 0.92, 95\% CI 0.78--1.07), even though these latter decreases were not significant. Considering cardiovascular mortality more specifically, the lowered incidence of death from ischemic heart disease (SMR $0.90)$ contrasted somewhat to the mortality from cerebrovascular disease (SMR 1.19). The SMR values did not, however, differ significantly from each other $(\mathrm{P}=0.4$, chi-square test). In spite of the lowered overall cancer mortality, a significant increased mortality from myeloma was found (SMR 3.41, 95\% CI 1.11-7.96). The increased mortality from stomach cancer was not statistically significant (SMR 1.42, 95\% CI $0.73-$ 2.47).

\section{Clinical diagnosis of stroke among the fishermen and matched referents}

The subtype of stroke (ischemic or hemorrhagic) was established by autopsy or angiography for six subjects (4 fishermen, 2 referents) and assigned an Allen Score of -30 (definitively infarction) or 50 (definitively hemorrhage). For the subjects who did not undergo definitive diagnostic procedures, the score was determined from the clinical records. The mean Allen Score was 12.9 (SD 26.3) for the fishermen and 4.9 (SD 25.3) for the referents, a finding indicating a somewhat increased incidence of hemorrhagic strokes among the fishermen. This difference was, however, not statistically significant in a multiple regression analysis allowing also for age at death, calendar year of death, and hospital code $(P=0.18)$. However, only $36 \%$ of the fishermen had negative scores (representing a $95 \%$ probability for infarction), as compared with $61 \%$ of the referents, and $29 \%$ of the fishermen had a score exceeding 30 (representing a $95 \%$ probability for hemorrhage), as compared with $22 \%$ of the referents.

\section{Cancer morbidity}

In spite of the significant overall decreased cancer mortality, the cancer incidence was not lowered (SMR = 1.11) (table 8). This discrepancy was mainly due to the increased incidence of squamous cell cancer of the skin (SMR 2.79, 95\% CI 1.73-4.36), as well as lip cancer (SMR 3.16, 95\% CI 1.16-6.88). None of the cohort members died from such tumors. A significantly increased incidence of stomach cancer (SMR 1.79, 95\% CI 1.09-2.88) was found. The increased risk of myeloma was not statistically significant (SMR 2.48, 95\% CI 0.68-6.36).

\section{Discussion}

The main result of the present study was that the fishermen had a decreased overall mortality, including a decreased risk for dying of cancer and a lowered risk for death from cardiovascular disease. 
The occurrence of "healthy worker selection" into employment may distort the results of a cohort study. This phenomenon is characterized typically by lower overall mortality, and it occurs because relatively healthy individuals are likely to gain employment (17). Two important characteristics of this selection bias is that the effect decreases with both length of time since entry into the cohort and with increasing age. As almost all fishermen start working at a young age, very few deaths were expected during the first 15 years of follow-up. The overall SMR for 15-29 years of follow-up was 0.94 , as compared with 0.87 for $\geq 30$ years of follow-up. Moreover, the overall SMR decreased with age (SMR 1.08 for < 55 years of age, SMR 0.98 for 55-69 years of age, and SMR 0.79 for $\geq 70$ years of age). Thus the decreased mortality in the present study was not due to "healthy worker selection." It should be stressed that many fishermen are not employees, but are self-employed. Therefore selection mechanisms known to exist for industrial cohorts may not be relevant for fishermen.

The dietary interviews showed a significantly higher fish consumption among the fishermen as compared with that of age-matched referents from the general population. This finding was validated by the relatively high plasma levels of n-3 PUFA and eicosapentaenoic acid in the fishermen, 10.4 and $2.6 \%$ weight/weight, respectively. In a previous study performed on nine subjects who never ate fish and were from the same county, the corresponding figures were 5.5 and 1.0 , and for 11 subjects eating mainly fat fish every day, the values were 12.5 and 3.5 , respectively (4).

The mean plasma selenium level among the fishermen was $90 \mu \mathrm{g} \cdot \mathrm{I}^{-1}$, a value almost identical to that of subjects with more than three fish meals a week $\left(91 \mu \mathrm{g} \cdot 1^{-1}\right)$ and higher than for subjects never eating fish $\left(80 \mu \mathrm{g} \cdot \mathrm{l}^{-1}\right)(18)$. This finding reflects the role of fish as a selenium source in the diet $(19,20)$. Methyl mercury from fish is found mainly in the erythrocytes (21), whereas the mercury levels in urine and plasma are relatively unaffected by fish consumption. This observation was confirmed by the present study. The plasma and urinary levels of mercury in the fishermen did not differ from that of males from the general population, but the levels of mercury in the red blood cells were doubled $\left(7.7\right.$ versus $3.9 \mathrm{ng} \cdot \mathrm{g}^{-1}$; unpublished results).

\section{Mortality from ischemic heart disease}

The initial hypothesis linking a high dietary intake of fish to a low risk for atherosclerotic cardiovascular disease was based on the reported low mortality from myocardial infarction among Greenland Inuits (5). The Inuits, with a diet rich in n-3 PUFA, have diminished platelet aggregability and prolonged bleeding time (7), as well as low levels of cholesterol, low-density lipoproteins, and triglycerides in serum, as compared with Danish subjects (9). Similar effects on hemostasis and serum lipids have been observed in healthy volunteers with a high dietary intake of n-3 PUFA $(8,10)$.

In Japan, where the fish consumption has traditionally been high, the incidence of ischemic heart disease is low, and it correlates with the level of fish consumption (22). A significant relation between fish consumption and decreasing risk for death from ischemic heart disease has also been observed in studies from The Netherlands, the United States, and Sweden (23$25)$. On the other hand, no such relations were found in studies from Hawaii and Norway (26-28).

British fishermen have been shown to have an increased mortality from ischemic heart disease (29). This excess risk has been ascribed to their heavy smoking. The fishermen in the present study also smoked more than the general population (table 5). Nevertheless, their mortality from ischemic heart disease was decreased, even if it did not reach full statistical significance.

The mortality from circulatory diseases among Swedish employees is about $10 \%$ lower than among the general population (30). This phenomenon has been explained by an unfavorable pattern of risk factors among the unemployed, such as hypertension and smoking (31). Persons with symptoms of ischemic heart disease may also have been withdrawn from the active work force. This potential bias introduced by incomparability between the study and reference groups is, however, not fully applicable for the present investigation. First, the fishermen in our study smoked more than the general population, and, second, the inclusion criterion for the cohort was at least one year of membership in the fishermen's organization, which is not incompatible with an early withdrawal from work. Most of the subjects stayed on as members even though they were no longer active fishermen.

\section{Cerebrovascular mortality}

In contrast to the low incidence of death from myocardial infarction among Inuits, an increased incidence of death due to stroke has been observed (11). It has been suggested that the reduced platelet aggregation ability in Inuits, due to a high dietary intake of n-3 PUFA, might well protect against coronary thrombosis but at the same time involves a greater bleeding tendency and thus increases the risk for hemorrhagic stroke (5). In the present study the SMR for mortality from cerebrovascular diseases was somewhat increased, although the difference was not significant. The median Allen Score was slightly, but not significantly, higher for the fishermen than for the referents. The relatively small number of observed cases limits, however, the statistical power to evaluate more than very large differences in scores. Another, ten times as large, cohort of Swedish fishermen, which is now being studied, will provide more conclusive evidence on this matter. 


\section{Cancer mortality and morbidity}

An almost significant $25 \%$ decrease in overall cancer mortality was observed among the fishermen. A possible reason may be their high fish consumption. Some epidemiologic studies suggest that populations consuming large amounts of marine oils have low cancer incidence rates, and animal studies indicate that dietary marine oils either inhibit tumor growth or lack the tumor-promoting effects of other dietary fats (32). The quantitative importance of these effects in humans are at present difficult to evaluate. The plasma selenium levels of the fishermen were, however, only marginally increased by high fish consumption, and a hypothetical cancer protective role of selenium (33) is therefore not a probable explanation of the low observed cancer mortality.

In spite of the decreased cancer mortality among the fishermen, the total cancer incidence did not differ from that of the reference population. The reason for this discrepancy was the about threefold risk for squamous cell cancer of the skin and lips. These tumors have a good prognosis and had not caused any deaths in the cohort. When the cohort was compared with the national population, the SMR for squamous cell cancer of the skin increased to 4.59. The reason for the higher incidence of this tumor in the county of Blekinge, from which the cohort was recruited, is not known. An increased risk for squamous cell cancer of the skin and lips among Swedish fishermen has also been observed previously (34). Possible causes are, besides occupational exposure to oils and tar, the relatively high exposure to ultraviolet light from outdoor work at sea. Considering specifically the site of the skin tumors, the SMR for face, neck, and upper limbs was 3.38 , as compared with 2.10 for the rest of the body. This finding supports the importance of occupational factors for these tumors. An interesting aspect is, however, that fish contain high levels of arsenic and are the main source of the human uptake of this element (35). Two to $10 \%$ of the arsenic in fish is inorganic (36). Oral exposure to inorganic arsenic has been considered to increase the risk for squamous cell cancer of the skin through a tumor promotive effect (35). Whether the dietary intake of inorganic arsenic from fish involves such a risk is not known (36).

\section{Multiple myeloma}

It is known that ionizing radiation may cause multiple myeloma (37), but no other specific environmental cause has been identified. Swedish farmers have lower than expected cancer incidence (38) but increased risk for multiple myeloma $(39,40)$. No plausible explanation for this increase in risk has been proposed. It is interesting that a similar increase was observed in the present study of fishermen. The data are still too sparse to allow an evaluation of the influence of dietary factors on this increase. The observed excess risk may, however, also be a chance finding. Studies on fishermen from other parts of Sweden may perhaps elucidate this question.

\section{Stomach cancer}

Dietary factors influence significantly the risk for stomach cancer. High salt intake, smoked food, and especially a low intake of fresh fruits and vegetables characterize dietary habits in areas with a high incidence of stomach cancer (41). It has been proposed that endogenous formation of $\mathrm{N}$-nitroso compounds in the stomach is an important causative factor (42). Ascorbic acid inhibits endogenous nitrosation (43), which may explain the protective effect of fresh fruits and vegetables. The increased incidence of stomach cancer among the fishermen was based on relatively few cases, and it is presently hard to draw any firm conclusions on whether the excess risk was caused by carcinogenic, persistent organochlorine compounds in the fish consumed or by, for example, other dietary factors. However, the fishermen in our study had not eaten less fresh fruits and vegetables than the referents.

\section{Fish from the Baltic Sea - good or bad food?}

In spite of the increased incidence of stomach cancer and myeloma among the fishermen, the overall mortality, including death from cancer and possibly also death from cardiovascular diseases, was decreased as compared with that of the reference population. The net effect of being a fisherman on health seems therefore to have been positive. Whether this finding reflects the increased fish consumption among the fishermen, or any other environmental or life-style factor, is difficult to determine. It is important to recognize that, in this type of epidemiologic study, it is not possible to measure directly the health effects of increased fish consumption. Considering the observed excess risk for squamous cell cancer, it is obvious that the main reason was the increased exposure to ultraviolet light, and not the fish consumption. Plausible explanations for the other observed excess risks are not that apparent.

\section{Acknowledgments}

This work was supported by grants from the Swedish Environmental Protection Agency, the Swedish Work Environment Fund, and the Medical Faculty, Lund University.

The authors thank Ms C Andersson and Ms K Sjöland for their help with establishing the cohort, Ms E Jonsson for performing the dietary interviews, and Ms A Akantis and Mr W Stomalovic for their analytical assistance.

\section{References}

1. US Environmental Protection Agency (EPA). Health assessment document for polychlorinated dibenzo-p- 
dioxins. Washington, DC: EPA, 1985. (600/8-84/ 0146.)

2. US Environmental Protection Agency (EPA). Health assessment document for polychlorinated dibenzofurans. Washington, DC: EPA, 1986. (600/8-86/018A.)

3. International Agency for Research on Cancer (IARC). Overall evaluation of carcinogenicity: an updating of IARC monographs volumes 1-42. Lyon: IARC, 1987. (IARC monographs on the evaluation of carcinogenic risks to humans; suppl 7.)

4. Svensson BG, Nilsson A, Hansson M, Rappe C, Åkesson B, Skerfving S. Exposure to dioxins and dibensofurans through the consumption of fish. N Engl J Med 1991;324:8-12.

5. Kronmann N, Green A. Epidemiological studies in the Upernavik district, Greenland: incidence of some chronic diseases 1950-74. Acta Med Scand 1980;208:401-6.

6. Dyerberg J, Bang HO. Haemostatic function and platelet polyunsaturated fatty acids in Eskimos. Lancet 1979; 2:433-5.

7. Dyerberg J, Bang HO, Stoffersen E, Moncada S, Vane JR. Eicosapentaenoic acid and prevention of thrombosis and atherosclerosis. Lancet 1978;2:117-9.

8. Thorngren M, Gustafson A. Effects of 11-week increase in dietary eicosapentaenoic acid on bleeding time, lipids, and platelet aggregation. Lancet 1981;2:1190-3.

9. Bang HO, Dyerberg J. Plasma lipids and lipoproteins in Greenlandic west coast Eskimos. Acta Med Scand 1972;192:85.

10. Harris WS, Connor WE, McMurray MP. The comparative reduction of the plasma lipids and lipoproteins by dietary polyunsaturated fats: salmon oil versus vegetable oil. Metabolism 1983;32:179-84.

11. Bjerregaard P, Gehlert Johansen L. Mortality patterns in Greenland: an analysis of potential years of life lost 1968-83. Arctic Med Res 1987;46:71-7.

12. Jacobsson L, Lindgärde F, Manthorpe R, Ảkesson B. Correlation of fatty acid composition of adipose tissue lipids and serum phosphatidylcholine and serum concentrations of micronutrients with disease duration in rheumatoid arthritis. Ann Rheum Dis 1990;49:901-5.

13. Molin M, Schütz A, Skerfving S, Sällsten G. Mobilized mercury in subjects with varying exposure to elemental mercury vapor. Int Arch Occup Environ Health 1991; 63:187- 92 .

14. La Londe L, Jean Y, Roberts KD, Chapdelaine A, Bleau G. Fluorometry of selenium in serum or urine. Clin Chem 1982;28:172-74.

15. Lustgarten JA, Wenk RE. Simple, rapid kinetic method for serum creatinine measurement. Clin Chem 1972;18: 1419-22.

16. Allen $\mathrm{CMC}$. Clinical diagnosis of the acute stroke syndrome. Q J Med 1983;208:15-23.

17. Checkoway H, Pearce NE, Crawford-Brown DJ. Research methods in occupational epidemiology. New York, NY: Oxford University Press, 1989. (Monographs in epidemiology and biostatistics; vol 13.)

18. Svensson B-G, Schütz A, Nilsson A, Ảkesson I, Ảkesson $B$, Skerfving $S$. Fish as a source of exposure to mercury and selenium. Sci Total Environ. In press.

19. Ringstad I, Fønnebø V. The Tromsø heart study: serum selenium in a low-risk population for cardiovascular disease and cancer and matched controls. Ann Clin Res 1987; $19: 351-4$.

20. Thorngren M, Ảkesson B. Effect of dietary fish on plasma selenium and its relation to haemostatic changes in healthy adults. Int J Vitam Nutr Res 1987;57:429-35.

21. Skerfving $S$. Methylmercury exposure, mercury levels in blood and hair, and health status in Swedes consuming contaminated fish. Toxicology 1974;2:3-23.

22. Hirai A, Terano T, Tamura Y, Yoshida S. Eicosapenatenoic acid and adult diseases in Japan: epidemiologi- cal and clinical aspects. J Intern Med 1989;225 suppl $1: 69-75$.

23. Kromhout D, Bosschieter EB, Lezenne Coulander C. The inverse relation between fish consumption and 20-year mortality from coronary heart disease. N Engl J Med 1985;312:1205-9.

24. Shekelle RB, Oglesby P, MacMillan Shyrock A, Stamler J. Fish consumption and mortality from coronary heart disease [letter]. N Engl J Med 1985;313:820.

25. Norell SE, Ahlbom A, Feychting M, Pedersen NL. Fish consumption and mortality from coronary heart disease. Br Med J 1986;293:426.

26. Curb JD, Reed JD. Fish consumption and mortality from coronary heart disease [letter]. N Engl J Med $1985 ; 313: 821$.

27. Vollset SE, Heuch I, Bjelke E. Fish consumption and mortality from coronary heart disease [letter] N Engl J Med 1985;313:820-1.

28. Simonsen T, Vårtun $\AA$, Lyngmo V, Nordøy A. Coronary heart disease, serum lipids, platelets and dietary fish in two communities in northern Norway. Acta Med Scand 1987;222:237-45.

29. Schilling RSF. Hazards of deep-sea fishing. Br J Ind Med $1971 ; 28: 27-35$.

30. Gustavsson P. Cancer and ischemic heart disease in occupational groups exposed to combustion products. Stockholm: Arbetarskyddsverket, 1989. (Arbete och hälsa 21.)

31. Diderichsen F, Lindberg G. Better health - but not for all: the Swedish public health report, 1987. Int J Health Serv 1989;19:221-55.

32. Reddy BS. Omega-3 fatty acids as anticancer agents. In: Nelson GJ, ed. Health effects of dietary fatty acids. Champaign, IL: American Oil Chemists' Society, 1991: 157-66.

33. World Health Organization (WHO). International programme on chemical safety: selenium. Geneva; WHO, 1987. (Environmental health criteria 58.)

34. Joint Group of Experts on the Scientific Aspects of Marine Pollution (GESAMP). The impact of carcinogenic substances on marine organisms and implications concerning public health. Geneva: WHO, 1985.

35. World Health Organization (WHO). International programme on chemical safety: arsenic. Geneva: WHO, 1981. (Environmental health criteria 18.)

36. Joint Group of Experts on the Scientific Aspects of Marine Pollution (GESAMP). Review of potentially harmful substances - arsenic, mercury and selenium. Geneva: WHO, 1986. (WHO Report Studies 28.)

37. Cuzick J. Radiation-induced myelomatosis. N Engl J Med 1981;304:204-10.

38. Wiklund $\mathbf{K}$. Swedish agricultural workers: a group with a decreased risk of cancer. Cancer 1983;51:566-8.

39. Steineck G, Wiklund K. Multiple myeloma in Swedish agricultural workers. Int J Epidemiol 1986;15:321-5.

40. McLaughlin JK, Linet MS, Stone BJ, Bloy WJ, Fraumeni JF, Malker HR, et al. Multiple myeloma and occupation in Sweden. Arch Environ Health 1988;43: $7-10$.

41. Schottenfeld D, Fraumeni JF. Cancer epidemiology and prevention. Philadelphia, PA: WB Saunders Company, 1982.

42. Correa P, Haenzel W, Cuello C, Archer M, Tannenbaum S. A model for gastric cancer epidemiology. Lancet $1975 ; 2: 58-60$.

43. Mirvish SS, Wallcave L, Eagen M, Shubik P. Ascorbatenitrite reaction: a possible means of blocking the formation of carcinogenic N-nitroso compounds. Science 1972;177:65-8.

Received for publication:15 November 1991 